\title{
Prevalence of pathogenic Escherichia coli from salad vegetable and fruits sold in Jakarta
}

\author{
Diana E. Waturangi', Fredy Hudiono and Edita Aliwarga
}

\begin{abstract}
Objective: Escherichia coli is a normal inhabitant of mammalian's gut, but some strains acquired virulence factor and became pathogenic. Enterotoxigenic E. coli (ETEC), enterohemorrhagic E. coli (EHEC), enteropathogenic E. coli (EPEC), enteroinvasive E. coli (EIEC), and enteroaggregative E. coli (EAEC) are among pathogenic strains of E. coli. Vegetables and fruits could be sources of transmission. Samples were collected and subjected to three-tubes Most Probable Number (MPN) analysis followed by Multiplex PCR. Six sets of primer encoding virulence genes were used: stx, ipah, aggr, eae, elt and est.

Results: From this study we found, the highest maximum number for the MPN result reached $>1100 \mathrm{MPN} / \mathrm{mL}$ and the lowest is $3 \mathrm{MPN} / \mathrm{mL}$. From first multiplex PCR showed 65 salad vegetable samples, $7.69 \%$ were positive and from the 63 fruit samples, $11.11 \%$ were positive. From second multiplex PCR for 76 isolates, 55 (72.37\%) isolates were aggR positive (EAEC), 12 (15.79\%) isolates were eae positive (EPEC), and 9 (11.84\%) were elt positive (ETEC). Antimicrobial resistance assay showed that $83.33 \%$ of the isolates were multi resistant. Resistances are observed to $10 \mathrm{\mu g}$ Ampicil-

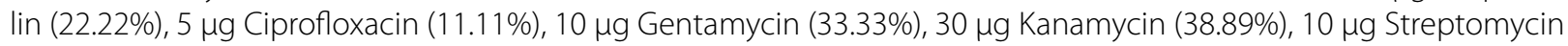
(55.56\%), 5 mg Trimethoprim (16.67\%), and 300 U Polymyxin B (61.11\%).
\end{abstract}

Keywords: Pathogenic Escherichia coli, Salad vegetables, Fruits, Multiplex PCR

\section{Introduction}

Escherichia coli, commonly found in the gut, is a commensal bacteria. However, some E. coli strains have acquired specific virulence factors by means of mobile genetic elements, such as plasmids, transposons, bacteriophages, and pathogenicity islands, and have evolved into pathogenic E. coli [1]. EPEC, ETEC, EHEC, EAEC, and EIEC are among the pathogenic strains of $E$. coli. The most recent outbreak from romaine lettuce was in 2011 in Germany, where 14 people were reported dead from the infection of enterohaemorrhagic E. coli (EHEC) [2].

Escherichia coli is transmitted via fecal-oral route. Its versatility and adaptability makes it very commonly found in water, soil, and food [3]. The use of raw manure as a fertilizer, gives rise to a high risk of bacterial contamination. The main concern in this research is the contamination of $E$. coli in salad vegetables and fruits. Salad

\footnotetext{
*Correspondence: Diana.Waturangi@atmajaya.ac.id
}

Faculty of Biotechnology, Atma Jaya Catholic University of Indonesia,

Jalan Jenderal Sudirman 51, Jakarta 12930, Indonesia vegetables are very common in Indonesia for they are part of Javanese traditional cuisine (lalaban) which are very famous throughout the country.

Water and soil can be sources of $E$. coli contamination to fresh products $[4,5]$. In most developing countries, including Indonesia, there is usually no adequate control and inspection regarding $E$. coli levels in foods sold in the market, including salad vegetables and fruits. This could lead to harm, especially when the people's awareness on this matter is very low. Several publications reported the presence of pathogenic E. coli in fresh vegetables and fruits $[6,7]$. Therefore, it is necessary to conduct a research on the detection and level of contamination of pathogenic $E$. coli from salad vegetables and fruits sold in traditional markets and grocery stores in Jakarta.

Identification of diarrheagenic $E$. coli strains needs to detect factors that determine the virulence of these organisms. For this purpose, PCR method, in particular multiplex PCR, is the most effective [8]. The primers used were primers that specifically targeted the virulence factor for each of the pathogenic strains of $E$. coli. eae gene 
for EPEC, because it was known for its intimate adhesion [9]. Shiga-like toxin encoding gene, stx, for EHEC [10]. Two primers were used for ETEC, which are the heat labile and heat stable enterotoxin gene, elt and est respectively [11]. EIEC bears the invasion plasmid antigen $\mathrm{H}$ gene, ipaH [12]. Lastly, aggR gene, the global regulator for EAEC virulence was used to detect EAEC [13].

\section{Main text \\ Methods \\ Samples collection}

A total of 65 salad vegetables and 63 fruits were collected from the traditional market, grocery stores, and street vendors in several areas in Jakarta between January to June 2013. For vegetables samples we collected (Solanum nigrum, Brassica oleracea, Daucus carota Coriandrum sativum, Cucumis sativus, Ocimum citriodorum, Lactuca sativa, Vigna radiate, Solanum melongena, Cosmos caudatus, Vigna unguiculata). With the number of samples per area: 14 samples from North, 18 from South, 9 from East, 10 from West, and 14 from Central Jakarta). While for fruits we collected (Averrhoa carambola, Solanum lycopersicum, Psidium guajava, Syzygium jambos, Malus domestica, Pyrus L., Vitis vinifera) with the number of samples per area: 12 samples from North, 12 from South, 13 from East, 11 from West and 14 samples from Central of Jakarta. Samples were transported to the laboratory on the same day after purchasing from vendors. The selection of samples based on criteria, fruits could be eaten directly without peeling and vegetables that often are eaten raw.

\section{Bacteria enumeration and isolation}

The three-tube MPN method was used for the enumeration, enrichment, and presumptive test to detect the presence of $E$. coli from the samples. The samples were cut into small pieces, $5 \mathrm{~g}$ of homogenized sample were submerged into $25 \mathrm{~mL}$ of EC Broth (Oxoid, Hampshire, England). For the fruits, only the skins were used. One milliliter of the inoculated broth were added to three tubes containing $9 \mathrm{~mL}$ of EC Broth (Oxoid, Hampshire, England). It was followed by serial dilutions to 100 - and 1000-fold dilution. The tubes were incubated at $42^{\circ} \mathrm{C}, 120 \mathrm{rpm}$ for $18-24 \mathrm{~h}$. The turbid tubes were considered presumptive. The turbid MPN were spread on Eosin methylene Blue (EMB) agar (Oxoid, Hampshire, England). The suspected colonies were selected randomly, we picked five colonies for each samples after that continued with several Biochemical tests such as indole, citrate, and MR-VP.

\section{DNA extraction}

One milliliter of the isolate were grown in Luria Broth (Oxoid, Hampshire, England) centrifuged at $12,000 \times g$ for 5 min., washed twice, re-suspended in $200 \mu \mathrm{L}$ of TE
(10 mM Tris, $1 \mathrm{mM}$ EDTA, pH 8.5), boiled for 10-15 min and used as cell lysates containing templates for PCR. The cell lysates were stored at $-20{ }^{\circ} \mathrm{C}$ until ready for analysis.

\section{Multiplex PCR}

We did two time multiplex PCR with same primers to detect the presence of virulence genes, firstly detection from the turbid MPN tubes directly, and the second is multiplex PCR for the E. coli isolates. The assay was carried out in reference to the method done by Toma et al. [14]. The PCR reaction consisted of $50 \mu \mathrm{L}$ reaction mixture containing $25 \mu \mathrm{L}$ of GoTaq green master mix ${ }^{\circledR}$ (Promega, Madison, USA), $1 \mu \mathrm{L}(10 \mathrm{pmol} / \mu \mathrm{L})$ of each 4 pairs primers: stx [15], ipaH [16], aggR [8] and eae [17] (1st BASE $^{\circledR}$, Singapore) $2,5 \mu \mathrm{L}(10 \mathrm{pmol} / \mu \mathrm{L})$ of each 2 pairs primers: elt [18] and est [19], $2.5 \mu \mathrm{L}$ of DNA template, and $4.5 \mu \mathrm{L}$ of nuclease free water. The amplification was conducted using a $\mathrm{C} 1000^{\mathrm{TM}}$ Thermal Cycler (Bio- $\operatorname{Rad}^{\circledR}$, USA) programmed with initial denaturation at $95{ }^{\circ} \mathrm{C}$ for $5 \mathrm{~min}$, followed by denaturation at $95{ }^{\circ} \mathrm{C}$ for $1 \mathrm{~min}, 30$ cycles of amplification with primer annealing stage at $52{ }^{\circ} \mathrm{C}$ for $1 \mathrm{~min}$, primer extension at $72{ }^{\circ} \mathrm{C}$ for $1 \mathrm{~min}$, final extension at $72{ }^{\circ} \mathrm{C}$ for $10 \mathrm{~min}$. The amplified products were analyzed by electrophoresis in $1.8 \%$ agarose gel with $1 \times$ Tris acetate (TAE) buffer at $\mathrm{pH} 8.0$ run at 60 volts for $90 \mathrm{~min}$, and visualized under UV light using GelDoc after stained with ethidium bromide (EtBr). The positive controls used for every pathogenic E. coli were from U.S. Naval Medical Research Unit Two (NAMRU-2) Culture Collection.

\section{Antimicrobial susceptibility testing}

Antibiotic susceptibility analysis was performed by a disc diffusion method (Kirby Bauer) using commercial disc. The McFarland 0.5 standard was used to prepare the inocula. Eight antibiotics discs (Oxoid, Hampshire, England) were used in this study ampicillin $(10 \mu \mathrm{g})$, Ciprofloxacin $(5 \mu \mathrm{g})$, Gentamycin $(10 \mu \mathrm{g})$, Kanamycin $(30 \mu \mathrm{g})$, Streptomycin $(10 \mu \mathrm{g})$, Trimethoprim $(5 \mu \mathrm{g})$, Polymyxin B (300U), Nalidixic Acid $(30 \mu \mathrm{g})$. We used guidelines established by Clinical and Laboratory Standard Institute (CLSI) [20].

\section{Results}

A total of 128 (65 salad vegetable and 63 fruit) samples sold in traditional market, street vendors and grocery stores from various regions in Jakarta were used in this study.

MPN analysis using three tube MPN method. Samples inoculated on EC Broth medium and the positive result showed by total turbid tubes then compared with MPN index. The highest maximum number for the $\mathrm{MPN}$ result reached $>1100 \mathrm{MPN} / \mathrm{g}$ and the lowest is $3 \mathrm{MPN} / \mathrm{g}$ indicating a wide range of the presumptive number of $E$. coli in salad vegetables and fruits (Table 1 ). 
Table 1 Most Probable Number (MPN/mL) and proportion of pathogenic E. coli detected positive for several virulence genes by PCR from defined regions of Jakarta, Indonesia

\begin{tabular}{|c|c|c|c|c|c|c|}
\hline \multirow[t]{2}{*}{ Sample type } & \multirow[t]{2}{*}{ Area } & \multirow[t]{2}{*}{ Sample ID } & \multirow[t]{2}{*}{ MPN/g } & \multicolumn{2}{|c|}{$95 \%$ confidence limits } & \multirow{2}{*}{$\begin{array}{l}\text { Percentage } \\
\text { of positive } \\
\text { samples }\end{array}$} \\
\hline & & & & Lower & Upper & \\
\hline \multirow[t]{47}{*}{ Vegetables } & \multirow[t]{14}{*}{ North Jakarta } & TIU-1 & 240 & 42 & 1000 & \multirow[t]{14}{*}{$7 \%$} \\
\hline & & KOU-1 & $<3$ & - & 9.5 & \\
\hline & & SLU-1 & 240 & 42 & 1000 & \\
\hline & & LEU-2 & $>1100$ & 420 & - & \\
\hline & & KMU-2 & 75 & 17 & 200 & \\
\hline & & KTU-2 & $>1100$ & 420 & - & \\
\hline & & TIU-3 & $>1100$ & 420 & - & \\
\hline & & WOU-4 & $>1100$ & 420 & - & \\
\hline & & KOU-6 & $>1100$ & 420 & - & \\
\hline & & TIU-7 & $>1100$ & 420 & - & \\
\hline & & KOU-7 & $>1100$ & 420 & - & \\
\hline & & WOU-7 & $>1100$ & 420 & - & \\
\hline & & KMU-8 & $>1100$ & 420 & - & \\
\hline & & KOU-8 & $>1100$ & 420 & - & \\
\hline & \multirow[t]{10}{*}{ West Jakarta } & KBB-1 & 1100 & 180 & 4100 & \multirow[t]{10}{*}{$0 \%$} \\
\hline & & $\mathrm{KOB}-1$ & $>1100$ & 420 & - & \\
\hline & & SLB-1 & $>1100$ & 420 & - & \\
\hline & & $\mathrm{T} \mid \mathrm{B}-1$ & 460 & 90 & 2000 & \\
\hline & & KOB-2 & $>1100$ & 420 & - & \\
\hline & & TIB-2 & $>1100$ & 420 & - & \\
\hline & & SLB-2 & $>1100$ & 420 & - & \\
\hline & & WOB-3 & 460 & 90 & 2000 & \\
\hline & & $\mathrm{KOB}-4$ & $>1100$ & 420 & - & \\
\hline & & TAB-6 & $>1100$ & 420 & - & \\
\hline & \multirow[t]{14}{*}{ Central Jakarta } & TRP-1 & $>1100$ & 420 & - & \multirow[t]{14}{*}{$14 \%$} \\
\hline & & KMP-1 & $>1100$ & 420 & - & \\
\hline & & KPP-1 & $>1100$ & 420 & - & \\
\hline & & $\mathrm{TIP}-1$ & $>1100$ & 420 & - & \\
\hline & & TAP-2 & 1100 & 180 & 4100 & \\
\hline & & KMP-2 & $>1100$ & 420 & - & \\
\hline & & $\mathrm{KOP}-4$ & 1100 & 180 & 4100 & \\
\hline & & $\mathrm{TIP}-4$ & 240 & 42 & 1000 & \\
\hline & & KOP-7 & $>1100$ & 420 & - & \\
\hline & & SLP-7 & $>1100$ & 420 & - & \\
\hline & & $\mathrm{KOP}-8$ & 460 & 90 & 2000 & \\
\hline & & SLP-8 & $>1100$ & 420 & - & \\
\hline & & TIP-8 & 93 & 18 & 420 & \\
\hline & & WOP-8 & $>1100$ & 420 & - & \\
\hline & \multirow[t]{9}{*}{ East Jakarta } & SLT-1 & $>1100$ & 420 & - & \multirow[t]{9}{*}{$11 \%$} \\
\hline & & KOT-1 & $>1100$ & 420 & - & \\
\hline & & KMT-1 & $>1100$ & 420 & - & \\
\hline & & TIT-2 & 460 & 90 & 2000 & \\
\hline & & SLT-2 & $>1100$ & 420 & - & \\
\hline & & KMT-2 & $>1100$ & 420 & - & \\
\hline & & TRT-2 & $>1100$ & 420 & - & \\
\hline & & TRT-5 & $>1100$ & 420 & - & \\
\hline & & LCT-5 & $>1100$ & 420 & - & \\
\hline
\end{tabular}


Table 1 (continued)

\begin{tabular}{|c|c|c|c|c|c|c|}
\hline \multirow[t]{2}{*}{ Sample type } & \multirow[t]{2}{*}{ Area } & \multirow[t]{2}{*}{ Sample ID } & \multirow[t]{2}{*}{ MPN/g } & \multicolumn{2}{|c|}{$95 \%$ confidence limits } & \multirow{2}{*}{$\begin{array}{l}\text { Percentage } \\
\text { of positive } \\
\text { samples }\end{array}$} \\
\hline & & & & Lower & Upper & \\
\hline & & KOS-1 & $>1100$ & 420 & - & \\
\hline & & $\mathrm{TIS}-1$ & $>1100$ & 420 & - & \\
\hline & & SLS-1 & $>1100$ & 420 & - & \\
\hline & & LES-1 & $>1100$ & 420 & - & \\
\hline & & SLS-2 & $>1100$ & 420 & - & \\
\hline & & $\mathrm{TIS}-2$ & 460 & 90 & 2000 & \\
\hline & South Jakarta & KOS-2 & 240 & 42 & 1000 & $6 \%$ \\
\hline & & SLS-3 & $>1100$ & 420 & - & \\
\hline & & $\mathrm{TIS}-3$ & 150 & 37 & 420 & \\
\hline & & SLS-4 & 460 & 90 & 2000 & \\
\hline & & TIS-4 & 460 & 90 & 2000 & \\
\hline & & WOS-4 & 75 & 17 & 200 & \\
\hline & & KNS-6 & $>1100$ & 420 & - & \\
\hline & & SLS-6 & $>1100$ & 420 & - & \\
\hline & & KOS-7 & $>1100$ & 420 & - & \\
\hline & & KOB-8 & $>1100$ & 420 & - & \\
\hline & & KMU-8 & $>1100$ & 420 & - & \\
\hline & & LES-8 & $>1100$ & 420 & - & \\
\hline \multirow[t]{30}{*}{ Fruits } & North Jakarta & TOU-3 & $>1100$ & 420 & - & $8 \%$ \\
\hline & & APU-4 & 9.2 & 1.4 & 38 & \\
\hline & & TOU-4 & 240 & 42 & 1000 & \\
\hline & & PIU-5 & $>1100$ & 420 & - & \\
\hline & & APU-5 & 240 & 42 & 1000 & \\
\hline & & $J B U-5$ & 1100 & 180 & 4100 & \\
\hline & & JAU-5 & $>1100$ & 420 & - & \\
\hline & & TOU-6 & $>1100$ & 420 & - & \\
\hline & & BLU-6 & $>1100$ & 420 & - & \\
\hline & & TOU-7 & 240 & 42 & 1000 & \\
\hline & & JAU-8 & $>1100$ & 420 & - & \\
\hline & & BLU-8 & $>1100$ & 420 & - & \\
\hline & West Jakarta & APB-3 & 3.6 & 0.17 & 18 & $22.27 \%$ \\
\hline & & BLB-3 & 43 & 9 & 180 & \\
\hline & & TOB-3 & $>1100$ & 420 & - & \\
\hline & & JAB-4 & 210 & 40 & 430 & \\
\hline & & JAB-5 & 1100 & 180 & 4100 & \\
\hline & & BLB-5 & 1100 & 180 & 4100 & \\
\hline & & APB-5 & 9.2 & 1.4 & 38 & \\
\hline & & TOB-5 & $>1100$ & 420 & - & \\
\hline & & BLB-6 & $>1100$ & 420 & - & \\
\hline & & TOB-6 & $>1100$ & 420 & - & \\
\hline & & JBB-6 & $>1100$ & 420 & - & \\
\hline & Central Jakarta & TOP-2 & $>1100$ & 420 & - & $6.67 \%$ \\
\hline & & PIP-3 & $>1100$ & 420 & - & \\
\hline & & AGP-3 & $<3$ & - & 9.5 & \\
\hline & & BLP-3 & 43 & 9 & 180 & \\
\hline & & TOP-3 & $<3$ & - & 9.5 & \\
\hline & & APP-4 & 150 & 37 & 420 & \\
\hline & & PIP-4 & 240 & 42 & 1000 & \\
\hline
\end{tabular}


Table 1 (continued)

\begin{tabular}{|c|c|c|c|c|c|c|}
\hline \multirow[t]{2}{*}{ Sample type } & \multirow[t]{2}{*}{ Area } & \multirow[t]{2}{*}{ Sample ID } & \multirow[t]{2}{*}{ MPN/g } & \multicolumn{2}{|c|}{$95 \%$ confidence limits } & \multirow{2}{*}{$\begin{array}{l}\text { Percentage } \\
\text { of positive } \\
\text { samples }\end{array}$} \\
\hline & & & & Lower & Upper & \\
\hline & & TOP-4 & 3.6 & 0.17 & 18 & \\
\hline & & APP-5 & 3.6 & 0.17 & 18 & \\
\hline & & TOP-5 & $>1100$ & 420 & - & \\
\hline & & APP-6 & 3.6 & 0.17 & 18 & \\
\hline & & BLP-6 & $>1100$ & 420 & - & \\
\hline & & TOP-6 & $>1100$ & 420 & - & \\
\hline & & BLP-7 & $>1100$ & 420 & - & \\
\hline & & TOP-7 & $>1100$ & 420 & - & \\
\hline & \multirow[t]{13}{*}{ East Jakarta } & BLT-4 & $>1100$ & 420 & - & $0 \%$ \\
\hline & & TOT-4 & $>1100$ & 420 & - & \\
\hline & & PIT-4 & $>1100$ & 420 & - & \\
\hline & & JAT-4 & $>1100$ & 420 & - & \\
\hline & & APT-5 & 240 & 42 & 1000 & \\
\hline & & BLT-5 & $>1100$ & 420 & - & \\
\hline & & PIT-5 & $>1100$ & 420 & - & \\
\hline & & JAT-5 & $>1100$ & 420 & - & \\
\hline & & PIT-6 & $>1100$ & 420 & - & \\
\hline & & BLT-6 & 460 & 90 & 1000 & \\
\hline & & AGT-6 & 75 & 37 & 420 & \\
\hline & & APT-6 & 93 & 18 & 420 & \\
\hline & & TOT-7 & $>1100$ & 420 & - & \\
\hline & \multirow[t]{13}{*}{ South Jakarta } & BLS-3 & 460 & 90 & 1000 & $16.67 \%$ \\
\hline & & TOS-3 & 43 & 9 & 180 & \\
\hline & & TOS-4 & $>1100$ & 420 & - & \\
\hline & & JAS-5 & $>1100$ & 420 & - & \\
\hline & & BLS-5 & 150 & 37 & 420 & \\
\hline & & $J B S-5$ & 150 & 37 & 420 & \\
\hline & & APS-6 & $<3$ & - & 9.5 & \\
\hline & & PIS-6 & $<3$ & - & 9.5 & \\
\hline & & TOS-7 & $>1100$ & 420 & - & \\
\hline & & BLS-7 & $>1100$ & 420 & - & \\
\hline & & APS-7 & 1100 & 180 & 4100 & \\
\hline & & TOS-8 & $>1100$ & 420 & - & \\
\hline & & TOP-5 & $>1100$ & 420 & - & \\
\hline
\end{tabular}

The presumptive tubes were subjected to first multiplex PCR assay. From 65 salad vegetable samples, 7.69\% were positive with percentage per region (North Jakarta is 7\%; $0 \%$ for West; $14 \%$ for Central; $11 \%$ for East and 6\% for South). While for 63 fruit samples, $11.11 \%$ were positive (North Jakarta 8\%; 27.3\% for West; 6.7\% for Central; $0 \%$ for East and $16.7 \%$ for South Jakarta). The positive MPN tubes, regardless of the result of the first multiplex PCR were spread in EMB agar and the suspected colonies, characterized by a metallic green-sheen appearance, were recovered for second multiplex PCR. A total of 76 suspected $E$. coli colonies were isolated and subjected to multiplex PCR assay. From the 76 isolates, 55 (72.37\%) isolates were $\operatorname{aggR}$ positive (EAEC), from 55 isolates (18 isolates was found from central of Jakarta; 2 isolates from North; 11 isolates from South and 24 isolates are from west of Jakarta). These isolates recovered from tomato; starfruit; guava; cucumber and cabbage. While 12 $(15.79 \%)$ isolates (11 isolates from central of Jakarta and 1 from south) were eae positive (EPEC), all of these isolates found from tomato. For ETEC 9 (11.84\%) were elt positive, all of these isolates recovered from south of Jakarta and from cabbage samples (Fig. 1 and Table 2). 


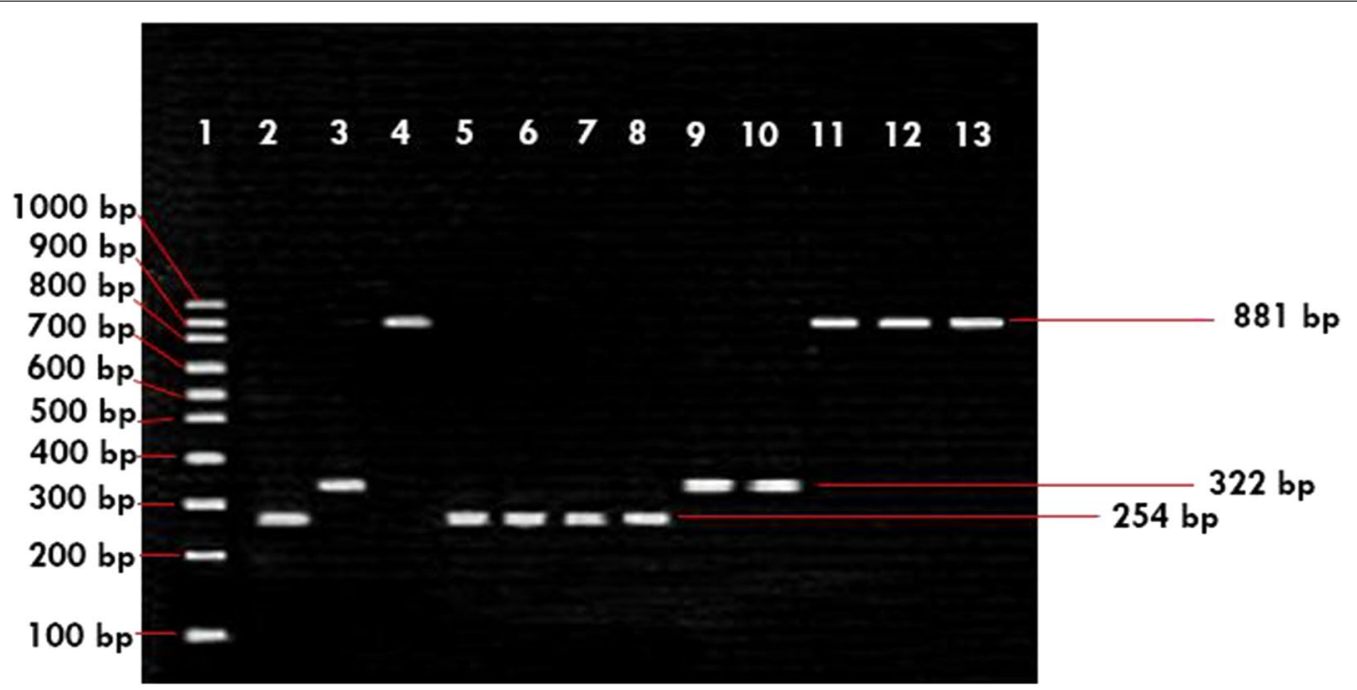

Fig. 1 Multiplex PCR of products from Escherichia coli isolates. Lanes: 1, 100-bp DNA ladder; 2, aggR positive control; 3, elt positive control; 4, eae positive control; 5, KOP.7.17 (EAEC); 6, KOP.7.20 (EAEC); 7, TIP.8.43 (EAEC); 8, TIP.8.44 (EAEC); 9, KOS.7.11 (ETEC); 10, KOP.7.14 (ETEC); 11 , TOP.6.12 (EPEC); 12, TOP.6.14 (EPEC); 13, TOS.8.1 (EPEC)

From Antimicrobial susceptibility analysis for eight antimicrobial agents were used, resistance was observed most commonly to Polymyxin B (61.11\%), Streptomycin (55.56\%), and Kanamycin (38.89\%), Gentamycin (25\%), Trimethoprim (33.33\%) and Ampicillin (22.22\%).

\section{Discussion}

The MPN result describes that most of salad vegetables and fruits sold in Jakarta were contaminated with Enterobacteria. This study showed that only 11 samples (8.59\%) were appropriate with the INS standard and 117 samples (91.41\%) were not appropriate with the INS standard. Based on Indonesian National Standard (INS), the maximum limit of coliform in fresh vegetable and fruit are $<3 \mathrm{MPN} / \mathrm{g}$ and $<20 \mathrm{MPN} / \mathrm{g}$ respectively [21]. Several factors can be sources of contamination is soil, water during planting, harvesting and distributing. The samples that we used majority are domestic products except for grape and pear fruits. In this study, we found that the prevalence of $E$. coli in local fruits were higher than import fruits. This might be because most of imported fruits were treated with preservative and pesticide to prevent microbial spoilage during distribution. Every region of Jakarta showed a high number of enterobacteria further imposing or requesting high awareness for hygiene and proper handling of foods.

Multiplex PCR from the MPN showed eae (3.17\%), $\operatorname{aggR}(6.25 \%)$, and elt (3\%) genes were found in this study indicating the presence of EPEC, EAEC, and ETEC. They are found in tomato (EPEC \& EAEC), starfruit (EAEC), guava (EAEC), cucumber (EAEC), cabbage and thai eggplant (ETEC) [22]. ETEC was responsible for many incidence of traveler's diarrhea and was easily transferred from one country to another country [11]. Pathogenic E. coli binds to the surfaces and forms an intimate attachment so that it can survive from frictional damage [23]. The prevalence of pathogenic $E$. coli in salad vegetable was found the highest in cabbage (data not shown). Tomato was the fruit with most prevalence of pathogenic E. coli followed by starfruit and guava (data not shown). But there were no trace back studies so we can not state where the contamination was derived from. Tomatoes are recognized as one of ten riskiest foods regulated by the U.S. Food and Drug Administration (FDA) up to 2011. This fruit also unfortunately has been repeatedly linked to foodborne illness and have caused at least 31 identified outbreaks since 1990, involving 3292 reported cases of illness [19].

EAEC was found to be dominant and may be an emerging pathogens in Jakarta. EAEC strains is the agent for an acute and persistent watery diarrhea in children, travelers and in individuals infected with HIV/AIDS. High prevalence of EAEC has also been reported from Tanzania and several regions in India [16]. Most of E. coli isolates showed resistance to one or more antimicrobial agents 
Table 2 Summary of the pathogenic E. coli isolates from Jakarta, Indonesia, for potential pathogenicity based on multiplex PCR

\begin{tabular}{|c|c|c|c|c|c|c|c|}
\hline \multirow[t]{2}{*}{ Isolate } & \multirow[t]{2}{*}{ Source } & \multicolumn{6}{|c|}{ Virulence genes } \\
\hline & & eae & stx & elt & est & $\operatorname{agg} \mathrm{R}$ & $i p a \mathrm{H}$ \\
\hline \multicolumn{8}{|l|}{ Vegetables } \\
\hline KOP.7.17 & Central Jakarta & & & & & + & \\
\hline KOP. 7.20 & & & & & & + & \\
\hline TIP.8.20 & & & & & & + & \\
\hline TIP.8.29 & & & & & & + & \\
\hline TIP.8.30 & & & & & & + & \\
\hline TIP.8.31 & & & & & & + & \\
\hline TIP.8.33 & & & & & & + & \\
\hline TIP.8.36 & & & & & & + & \\
\hline TIP.8.37 & & & & & & + & \\
\hline TIP.8.38 & & & & & & + & \\
\hline TIP.8.39 & & & & & & + & \\
\hline TIP.8.40 & & & & & & + & \\
\hline TIP.8.42 & & & & & & + & \\
\hline TIP.8.43 & & & & & & + & \\
\hline TIP.8.44 & & & & & & + & \\
\hline TIP.8.45 & & & & & & + & \\
\hline TIP.8.46 & & & & & & + & \\
\hline TIP.8.47 & & & & & & + & \\
\hline KOS. 7.3 & South Jakarta & & & + & & & \\
\hline KOS. 7.4 & & & & + & & & \\
\hline KOS. 7.5 & & & & + & & & \\
\hline KOS. 7.8 & & & & + & & & \\
\hline KOS. 7.10 & & & & + & & & \\
\hline KOS. 7.11 & & & & + & & & \\
\hline KOS. 7.14 & & & & + & & & \\
\hline KOS. 7.15 & & & & + & & & \\
\hline KOS. 7.16 & & & & + & & & \\
\hline \multicolumn{8}{|l|}{ Fruits } \\
\hline BLU. 6.29 & North Jakarta & & & & & + & \\
\hline BLU. 6.30 & & & & & & + & \\
\hline TOP. 6.1 & Central Jakarta & + & & & & & \\
\hline TOP. 6.2 & & + & & & & & \\
\hline TOP. 6.4 & & + & & & & & \\
\hline TOP. 6.5 & & + & & & & & \\
\hline TOP. 6.6 & & + & & & & & \\
\hline TOP. 6.7 & & + & & & & & \\
\hline TOP. 6.8 & & + & & & & & \\
\hline TOP. 6.11 & & + & & & & & \\
\hline TOP. 6.12 & & + & & & & & \\
\hline TOP. 6.14 & & + & & & & & \\
\hline TOP. 6.15 & & + & & & & & \\
\hline TOS. 7.2 & South Jakarta & & & & & + & \\
\hline TOS. 7.3 & & & & & & + & \\
\hline TOS. 7.4 & & & & & & + & \\
\hline TOS. 7.5 & & & & & & + & \\
\hline TOS. 7.6 & & & & & & + & \\
\hline
\end{tabular}


Table 2 (continued)

\begin{tabular}{|c|c|c|c|c|c|c|c|}
\hline \multirow[t]{2}{*}{ Isolate } & \multirow[t]{2}{*}{ Source } & \multicolumn{6}{|c|}{ Virulence genes } \\
\hline & & eae & stx & elt & est & $\operatorname{agg} \mathrm{R}$ & $i p a \mathrm{H}$ \\
\hline TOS. 7.7 & & & & & & + & \\
\hline TOS. 7.8 & & & & & & + & \\
\hline TOS. 7.11 & & & & & & + & \\
\hline TOS. 8.1 & & + & & & & & \\
\hline JBB. 6.1 & & & & & & + & \\
\hline JBB. 6.4 & & & & & & + & \\
\hline JBB. 6.5 & & & & & & + & \\
\hline BLB 6.1 & West Jakarta & & & & & + & \\
\hline BLB 6.9 & & & & & & + & \\
\hline TOB. 6.1 .8 & & & & & & + & \\
\hline TOB. 6.1.10 & & & & & & + & \\
\hline TOB. 6.1.11 & & & & & & + & \\
\hline TOB. 6.1.12 & & & & & & + & \\
\hline TOB. 6.1 .13 & & & & & & + & \\
\hline TOB. 6.1.14 & & & & & & + & \\
\hline TOB. 6.1.15 & & & & & & + & \\
\hline TOB. 6.1.16 & & & & & & + & \\
\hline TOB. 6.2.1 & & & & & & + & \\
\hline TOB. 6.2 .2 & & & & & & + & \\
\hline TOB. 6.2 .3 & & & & & & + & \\
\hline TOB. 6.2.4 & & & & & & + & \\
\hline TOB. 6.2 .5 & & & & & & + & \\
\hline TOB. 6.2 .6 & & & & & & + & \\
\hline TOB. 6.2 .9 & & & & & & + & \\
\hline TOB. 6.2 .10 & & & & & & + & \\
\hline TOB. 6.2.11 & & & & & & + & \\
\hline TOB. 6.2.12 & & & & & & + & \\
\hline TOB. 6.2 .13 & & & & & & + & \\
\hline TOB. 6.2 .14 & & & & & & + & \\
\hline TOB. 6.2 .15 & & & & & & + & \\
\hline TOB. 6.2 .16 & & & & & & + & \\
\hline
\end{tabular}

The first two letters represent the vegetable and the fruit name. KO: cabbage; TI: cucumber; TO: tomato; AP: Apple; PI: pear; JB: guava; JA: rose apple; AG: grape; BL: starfruit. The third letter represent the area; U: North Jakarta; S: South Jakarta; B: West Jakarta; T: East Jakarta; P: Central Jakarta

(Polymyxin B, Streptomycin, and Kanamycin), indicating that most of $E$. coli recovered from the salad vegetable and fruit samples in Jakarta are multi-drug resistant.

\section{Conclusion}

The result demonstrated that salad vegetables and fruits sold in Jakarta were contaminated with pathogenic E. coli including: EPEC, EAEC, and ETEC. These bacteria were detected in four out of five regions of Jakarta. Despite the low prevalence of pathogenic $E$. coli, it indicates that the presence of pathogenic $E$. coli were evenly spread in many salad vegetables and fruits sold in Jakarta. Multiplex PCR assay is appropriate tool to detect the presence of pathogenic $E$. coli in salad vegetables and fruits.

\section{Limitation}

The presumptive MPN result and Multiplex PCR might detect other $E$. coli which also have similar virulence genes.

\section{Abbreviation \\ MPN: Most Probable Number.}

\section{Authors' contributions}

DEW made substantial contributions to conception, design, and interpretation of data; $\mathrm{FH}$ and EA contribute in acquisition of data and analysis. All authors read and approved the final manuscript.

\section{Acknowledgements}

Not applicable. 


\section{Competing interests}

The authors declare that they have no competing interests.

\section{Availability of data and materials}

All data generated or analysed during this study are included in this published article.

\section{Consent for publication}

Not applicable.

\section{Ethics approval and consent to participate}

Not applicable.

\section{Funding}

This research was supported by a grant from the International Foundation for Science (IFS) project number E/4626-2F. Karlavägen 108, 5 th floor, S- 11526 Stockholm, Sweden. The funding body give advice in the study design.

\section{Publisher's Note}

Springer Nature remains neutral with regard to jurisdictional claims in published maps and institutional affiliations.

Received: 24 February 2019 Accepted: 25 April 2019

Published online: 02 May 2019

\section{References}

1. Sethabutr O, Venkatesan M, Murphy GS, Eampokalap B, Hoge CW, Echeverria P. Detection of Shigellae and enteroinvasive Escherichia coli by amplification of the invasion plasmid antigen $\mathrm{H}$ DNA sequence in patients with dysentery. J Infect Dis. 1993;167:458-61.

2. Buchholz Md, et al. German Outbreak of Escherichia coli 0104:H4 Associated with Sprouts. New Engl J Med. 2011;365(19):1763-70.

3. Kljujev I, Raicevic V, Andrews S, Jackson R, Lalevic B, Dorati F. Transmission of E. coli from contaminated irrigation water and soil to plant tissue. J Hyg Eng Design. 2012; Original scientific paper, UDC 631.461:579.842.11; 628.034.3:579.842.11.

4. Chekabab SM, Veillette JP, Dozois CM, Harel J. The ecological habitat and transmission of Escherichia coli O157:H7. FEMS Microbiol Lett. 2013;341:1-12.

5. Solomon EB, Yaron S, Matthews KR. Transmission of Escherichia coli 0157:H7 from contaminated manure and irrigation water to lettuce plant tissue and its subsequent internalization. Appl Environ Microbiol. 2002;68(1):397-400.

6. Kim HJ, Koo M, Jeong AR, et al. Occurrence of pathogenic Escherichia coli in commercially available fresh vegetable products in Korea. J Korean Soc Appl Biol Chem. 2014;57:367.

7. Moses AE, James RA, Ekanem US. Prevalence of Escherichia coli 0157 in fruits, vegetables and animal fecal waste used as manure in farms of some Communities of Akwa Ibom State-Nigeria. Central Afr J Public Health. 2016;1:22-7

8. Ratchtrachenchai OA, Subpasu S, Ito K. Investigation on enteroaggregative Escherichia coli infection by multiplex PCR. Bull Dept Med Sci. 1997:39:211-20.
9. Blanco M, et al. Typing of intimin (eae) genes from enteropathogenic Escherichia coli (EPEC) isolated from children with diarrhoea in Montevideo, Uruguay: identification of two novel intimin variants $(\mu \mathrm{B}$ and $\xi R / \beta 2 B)$. J Med Microbiol. 2006;55(9):1 165-74.

10. Bugarel, et al. Virulence gene profiling of enterohemorrhagic (EHEC) and enteropathogenic (EPEC) Escherichia coli strains: a basis for molecular risk assessment of typical and atypical EPEC strains. BMC Mircobiol. 2011;11:142.

11. Nataro JP, et al. Diarrheagenic Escherichia coli infection in Baltimore, Maryland, and New Haven, Connecticut. J Clin Infect Dis. 2006;43:402-7.

12. Raju B, Ballal M. Multidrug resistant enteroaggregative Escherichia coli diarrhea in rural southern Indian population. Scand J Infect Dis. 2009:41:105-8.

13. Boll EJ, et al. Role of enteroaggregative Escherichia coli virulence factors in uropathogenesis. J Infect Immun. 2013;81(4):1164-71.

14. Toma $C$, et al. Multiplex PCR assay for identification of human diarrheagenic Escherichia coli. J Clin Microbiol. 2003;41(6):2669-71.

15. Yamasaki $\mathrm{S}$, Lin Z, Shirai H, Terai A, Oku Y, Ito H, Ohmura M, Karasawa T, Tsukamoto T, Kurazono H, Takeda Y. Typing of verotoxins by DNA colony hybridization with poly- and oligonucleotide probes, a bead-enzymelinked immunosorbent assay, and polymerase chain reaction. Microbiol Immunol. 1996:40:345-52

16. Thiem VuD, et al. Detection of Shigella by a PCR assay targeting the ipaH gene suggests increased prevalence of Shigellosis in Nha Trang, Vietnam. J Clin Microbiol. 2004:42(5):2031-5.

17. Oswald E, Schmidt H, Morabito S, Karch H, Marche`s O, Caprioli A. Typing of intimin genes in human and animal enterohemorrhagic and enteropathogenic Escherichia coli: characterization of a new intimin variant. Infect Immun. 2000:68:64-71.

18. Tamanai-Shacoori Z, Jolivet-Gougeon A. Detection of enterotoxigenic Escherichia coli in water by polymerase chain reaction amplification and hybridization. Can J Microbiol. 1994;40:243-9.

19. Hornes E, Wasteson Y, Olsvik O. Detection of Escherichia coli heat-stable enterotoxin genes in pig stool specimens by an immobilized, colorimetric, nested polymerase chain reaction. J Clin Microbiol. 1991:29:2375-9.

20. Clinical and Laboratory Standard Institute. Performance standards for antimicrobial susceptibility testing. In: 15th informational supplement. CLSI/NCCLS M100-S15. Clinical and Laboratory Standard Institute, Wayne, PA. 2005.

21. Qadri F, et al. Enterotoxigenic Escherichia coli in developing countries: epidemiology, microbiology, clinical features, treatment, and prevention. J Clin Microbiol Rev. 2005:18(3):465-83.

22. Klein S, Tian A, Witmer J, DeWaal CS. The FDA top ten: the riskiest foods regulated by the U.S. Food and Drug Administration. Center for Science in the Public Interest (CSPI) 2009.

23. Clarke SC, Haigh RD, Freestone PPE, Williams PH. Virulence of enteropathogenic Escherichia coli, a global pathogen. J Clin Microbiol Rev. 2003;16(3):365-78.

Ready to submit your research? Choose BMC and benefit from

- fast, convenient online submission

- thorough peer review by experienced researchers in your field

- rapid publication on acceptance

- support for research data, including large and complex data types

- gold Open Access which fosters wider collaboration and increased citations

- maximum visibility for your research: over 100M website views per year

At $\mathrm{BMC}$, research is always in progress.

Learn more biomedcentral.com/submissions 